\section{Inheritance of the Foliar Variegation Pattern from Aglaonema nitidum (Jack) Kunth 'Ernesto's Favorite'}

\section{R.J. Henny}

Institute of Food and Agricultural Sciences, University of Florida, Central Florida Research and Education Center, 2807 Binion Road, Apopka, FL 32703

Additional index words. foliage plant, breeding, genetics

The attractive foliar variegation patterns of Aglaonema contribute to their value as ornamental foliage plants. Initially, the presence of foliar variegation in Aglaonema was reported to be dominant to nonvariegation and under the control of nuclear genes (Henny, 1983a). A subsequent study identified the $V$ gene and its series of five dominant alleles, each determining a distinct variegation pattern (Henny, 1986). Alleles were codominant, which allowed for combinations of any two patterns in the same plant. Nonvariegated plants were of the $v v$ genotype.

Aglaonema nitidum 'Ernesto's Favorite' is a recently discovered cultivar native to Thailand (Brown, 1984). This cultivar's variegation is a silvery-gray band in the middle of the leaf that is about one-half the width of the leaf and is centered around the midrib (Fig. 1). This report details the inheritance of this variegation pattern.

Stock plants and hybrids were grown at $80 \%$ light exclusion in shaded greenhouses under natural photoperiod in the range 1832C. Parental plants used in test crosses were induced to flower using a single foliar spray of $250 \mathrm{ppm}$ gibberellic acid (Henny, 1983b). Fresh pollen was used in all crosses and inflorescences were wrapped with wet paper toweling and enclosed in plastic bags for 1 day following pollination to promote pollen germination and seed set (Henny, 1985). Seeds were cleaned before planting to speed germination (Henny and Fooshee, 1985). Hybrids were evaluated for variegation pattern when they were 11 year old and had produced eight to 10 leaves.

Received for publication 31 Dec. 1990. Accepted for publication 17 Oct. 1991. Florida Agricultural Experiment Stations Journal Series no. R-01250. The cost of publishing this paper was defrayed in part by the payment of page charges. Under postal regulations, this paper therefore must be hereby marked advertisement solely to indicate this fact.

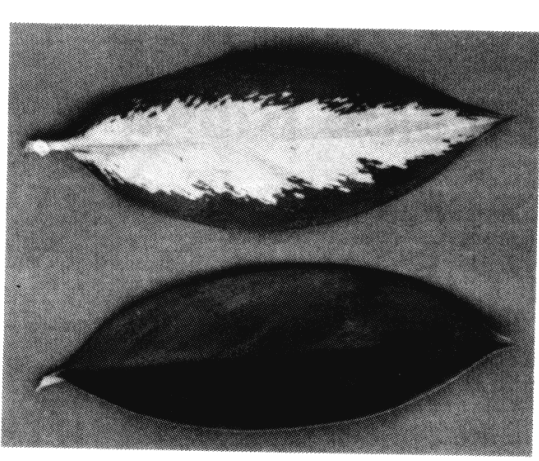

Fig. 1. Foliar variegation pattern of Aglaonema nitidum 'Ernesto's Favorite' (top) and nonvariegated leaf from seedling obtained by self-pollination (bottom).

Pollinations included selfing of 'Ernesto's Favorite,' and crossing it with 'Curtisii' (genotype $V^{\circ} \mathrm{v}$ ).We also used our own hybrids, \#1501 and \#1502, both with compound patterns and genotype $\mathrm{V}^{\mathrm{mn}} \mathrm{V}^{\mathrm{t}}$ (Henny, 1986), as females in crosses with 'Ernesto's Favorite'.

Self-pollination of 'Ernesto's Favorite' produced 54 seedlings, of which 42 expressed the parental variegation pattern and 12 were nonvariegated (Table 1). Crossing 'Ernesto's Favorite' with hybrids 1501 and 1502 resulted in four classes of variegated offspring that segregated in a 1:1:1:1 ratio. This ratio included each of the hybrid's compound patterns expressed individually and in combination with the 'Ernesto's Favorite' pattern (Table 1).

These results indicate that the 'Ernesto's Favorite' pattern was controlled by a single dominant allele. The allele has been labeled $V^{e f}$ and is the sixth allele of the V-gene to be identified. The 'Ernesto's Favorite' stock plants used in this study were heterozygous for the $V^{e f}$ allele. Since the parental plants

were collected in the wild from naturally crossing populations, it is likely that both heterozygous and homozygous individuals would be obtained.

\section{Literature Cited}

Brown, F.B. 1984. The new aglaonemas of Thailand. Aroideana 7(2):42-52.

Henny, R.J. 1983a. Inheritance of foliar variegation in three Aglaonema species. J. Hered. 74:475-476.

Henny, R.J. 1983b. Flowering of Aglaonema commutatum 'Treubii' following treatment with gibberellic acid. HortScience 18:374.

Henny, R.J. 1985. In vivo pollen germination of Aglaonema affected by relative humidity. HortScience 20:142-143.

Henny, R.J. 1986. Single locus, multiallelic inheritance of foliar variegation in Aglaonema. J. Hered. 77:214-215.

Henny, R.J. and W.C. Fooshee. 1985. Cleaning Aglaonema seeds promotes germination and growth of seedlings. CFREC-Apopka Res. Rpt. RH-85-18:1-2.
Table 1. Segregation data for foliar variegation from crosses involving Aglaonema nitidum 'Ernesto's Favorite'.

\begin{tabular}{|c|c|c|c|c|c|c|c|c|c|}
\hline \multicolumn{3}{|c|}{$\begin{array}{r}\text { Cross } \\
\end{array}$} & \multirow{2}{*}{\multicolumn{2}{|c|}{$\begin{array}{c}\text { Parental } \\
\text { genotypes }\end{array}$}} & \multirow{3}{*}{$\begin{array}{l}\text { Total no. } \\
\text { seedlings }\end{array}$} & \multirow{3}{*}{$\begin{array}{c}\text { Hybrid genotypes/ } \\
\text { frequency }\end{array}$} & \multirow{3}{*}{$\begin{array}{l}\text { Ratio } \\
\text { tested }\end{array}$} & \multirow[b]{3}{*}{$\chi^{2}$} & \multirow[b]{3}{*}{$P$} \\
\hline \multirow{2}{*}{$\begin{array}{c}\text { Female } \\
-\left(\mathrm{P}_{1}\right) \\
\end{array}$} & & \multirow{2}{*}{$\begin{array}{c}\text { Male } \\
\left(P_{2}\right)\end{array}$} & & & & & & & \\
\hline & & & $P_{1}$ & $\mathbf{P}_{2}$ & & & & & \\
\hline \multicolumn{10}{|l|}{$\begin{array}{l}\text { Ernesto's } \\
\text { Favorite }\end{array}$} \\
\hline \multicolumn{10}{|c|}{$\begin{array}{lll}3: 1 & 0.22 & 0.75-0.50\end{array}$} \\
\hline Favorite & $x$ & Curtisii & $V^{\text {er }} \mathrm{v}$ & $V^{\circ} \mathrm{v}$ & 14 & $\begin{array}{c}V^{\mathrm{ef}} \mathrm{v} / 5 ; V^{\mathrm{er}} \mathrm{Vc} / 2 ; \\
V^{\mathrm{c}} \mathrm{v} / 4 ; v v / 3\end{array}$ & $1: 1: 1: 1$ & 1.43 & $0.75-0.50$ \\
\hline \multirow[t]{2}{*}{$1501^{z}$} & $x$ & Ernesto's & & & & $2 / 4, D V / 3$ & & & \\
\hline & $x$ & $\begin{array}{l}\text { Favorite } \\
\text { Ernesto's }\end{array}$ & $V^{\mathrm{mn}} \mathrm{V}$ & $V^{\text {ef }} \mathbf{v}$ & 28 & $\begin{array}{c}V^{\mathrm{ef}} V^{\mathrm{mn}} / 9 ; V^{\mathrm{er}} V^{\mathrm{t}} / 6 ; \\
V^{\mathrm{mn}} \mathrm{v} / 7 ; V^{\mathrm{t}} \mathrm{v} / 6\end{array}$ & 1:1:1:1 & 0.86 & $0.90-0.75$ \\
\hline $1502^{z}$ & & Favorite & $V^{m n} V^{t t}$ & $V^{e f} \mathrm{v}$ & 79 & $\begin{array}{c}V^{\mathrm{er}} V^{\mathrm{mn}} / 23 ; V^{\mathrm{er}} \mathrm{V}^{\mathrm{tt}} / 23 ; \\
V^{\mathrm{mn}} \mathrm{v} / 16 ; V^{\mathrm{t}} \mathrm{v} / 17\end{array}$ & $1: 1: 1: 1$ & 2.16 & $0.75-0.50$ \\
\hline
\end{tabular}

${ }^{7}$ Hybrids developed by the author. 